How to cite: Rusu, C. (2019) Severe Convective Wind in North-Western Romania. 2019"Air and Water - Components of the Environment" Conference Proceedings, Cluj-Napoca, Romania, p. 151-162, DOI: 10.24193/AWC2019 15.

\title{
SEVERE CONVECTIVE WIND IN NORTH-WESTERN ROMANIA
}

\author{
Cristian RUSU ${ }^{I}$ 冈 \\ DOI: 10.24193/AWC2019_15
}

\begin{abstract}
Romania. The present paper aims a comparative analysis of the cases when the convective wind gusts reached and exceeded $25 \mathrm{~m} / \mathrm{s}$ in the warm season (April-September) of the years 2012-2017. In the range studied were identified 6 cases: 2 cases in 2012, one case in 2015, and 3 cases in 2017. The $90 \mathrm{~km} / \mathrm{h}$ limit registers on level 10 on the Beaufort scale, which may cause uprooting trees and affecting the structure of the buildings. identifies the synoptic situations that led to the emergence of convective systems by analyzing the temperature and geopotential parameters at standard levels. The degree of instability of the atmosphere is assessed on the basis of instability indices (CAPE, LI, VTI). The mesoscale analysis was realized and the evolution of the systems that generated the wind was monitored by satellite and radar imaging.
\end{abstract}

Keywords: north-western Romania, convective wind, squall line, derecho, instability

\section{INTRODUCTION}

In this paper were analyzed the severe wind intensification associated with the convective systems, with high potential for damages, which reached and exceeded $25 \mathrm{~m} / \mathrm{s}$, recorded during the warm season of April-September 2012-2017 (Fig.1).

Wind speed of $25 \mathrm{~m} / \mathrm{s}$ or more represents a severe storm, according to National Weather Service.

For northwestern Romania has been done the spatial distribution of the frequency for the convective cells, detected by Oradea and Bobohalma radars, which may generate wind gusts exceeding $21 \mathrm{~m} / \mathrm{s}$ (intensity calculated using the hight of the cell and VIL-vertically integrated liquid parameter) (Maier 2011) for the summer months between 2004 and 2011.

According to data from meteorological stations and media reports, the most severe convective wind was recorded on September 17, 2017 when wind gusts up to $41 \mathrm{~m} / \mathrm{s}$ at Huedin, $27 \mathrm{~m} / \mathrm{s}$ at Cluj Napoca, Târgu Lăpus, $26 \mathrm{~m} / \mathrm{s}$ at Baia Mare, Zalău, $25 \mathrm{~m} / \mathrm{s}$ at Bistrița, Sighetu Marmatiei, the rainfall exceeds 40 ... 50 1/sqm, isolated $791 / \mathrm{sqm}$, numerous hail cases were recorded. Because of the various objects or the trees shot down by the strong winds, there were 145 victims, out of which 8 people died and 137 people were injured.

The second case of strong convective wind was recorded in the northwest of Transylvania on May 25, 2015, when it reached $31 \mathrm{~m} / \mathrm{s}$ in Satu Mare and $25 \mathrm{~m} / \mathrm{s}$ at Supuru

\footnotetext{
1 National Meteorological Administration, Regional Meteorological Center Transilvania Nord, 400213 Cluj-Napoca, Romania, e-mail: vira_cristi@yahoo.com
} 
de Jos. This storm was associated with medium and large hail $(5.2 \mathrm{~cm}$ Satu Mare, $7 \mathrm{~cm}$ at Supuru de Jos, Sărmăşag $4 \mathrm{~cm}$, Nuşfalău, Zalnoc (the size of the dove egg), Şimleul Silvaniei, Bănişor, Gherţa Mare, Cichirlău, Valea Vinului. The rains were torrential: 26.1 1/sqm at Dara (20 '), 20 1/sqm Valea Vinului (30'), 27.4 1/sqm Bănişor (20 '), 31.7 1/sqm Cichirlău (40 '), 28,2 1/sqm Gherţa Mare (15'). In total, 36 localities were affected.

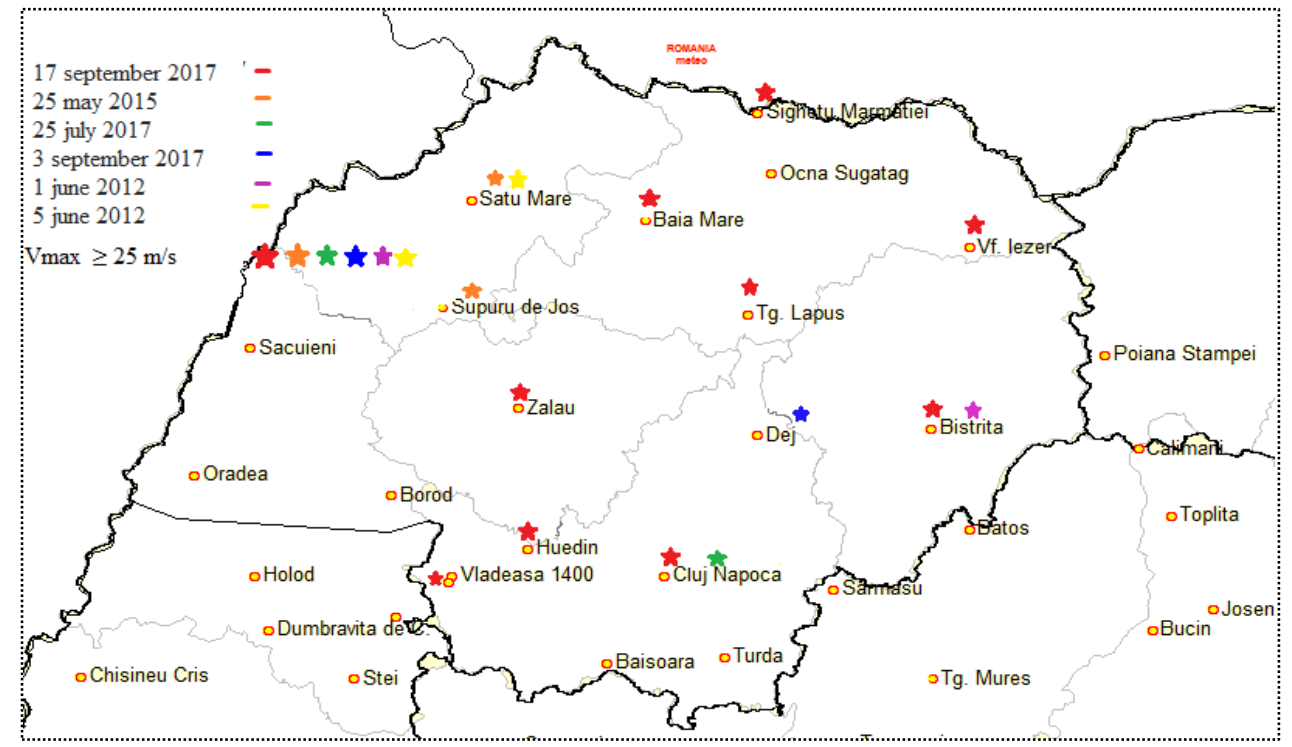

Fig. 1. Spatial and temporal distribution of convective winds with a gust $\geq 25 \mathrm{~m} / \mathrm{s}$

In the other cases, the affected area is smaller. On July 25, 2017, the wind in ClujNapoca reached $26 \mathrm{~m} / \mathrm{s}$. There were also wind gusts in the area, between $20-25 \mathrm{~m} / \mathrm{s}$ in Târgu Lăpus and between 15-20 m/s in Huedin, Dej, Bistriţa and Sighetu Marmaţiei, torrential rains 110.4 1/sqm at Firiza Dam) and hail. At Dej on September 3, 2017 there were $26 \mathrm{~m} / \mathrm{s}$, hail. "In total, 5 blocks in Dej were left without a roof and other dozens of buildings were seriously damaged. " The strong wind also broke dozens of trees causing significant damage (www.dejeanul.ro). " During the day, there were also convective wind gusts with speeds between $15-20 \mathrm{~m} / \mathrm{s}$ in Cluj-Napoca, Huedin and Târgu Lăpus.

On June 1, 2012 in Bistriţa were registered $25 \mathrm{~m} / \mathrm{s}$. If in the city of Bistriţa the damage was not so great, the squall line being in the early stage of development, but when it reached the mountain area it develops into a supercellular system, with the most affected area being the commune of Coroieni. "... the mayor of the locality, said: The storm has pulled trees from the ground, broke branches, uncovered houses with durable roofs. I saw how a walnut with a diameter of about $60 \mathrm{~cm}$ was taken out of the ground, lifted up in the air and worn by a few meters. Incredible. And this took only two minutes! ... but the biggest ravages were on the Valea Mare river, where over 50 trees were simply pulled out of the ground. More than 8 households remained without their tiles after strong gusts." (www.timponline.ro). Wind intensification with speeds between $15-20 \mathrm{~m} / \mathrm{s}$ are recorded at Satu Mare, Baia Mare and Cluj-Napoca. In the case from June 5, 2012, when the wind reached $25 \mathrm{~m} / \mathrm{s}$ in 
Satu Mare no damages were identified and wind intensifications with lower speeds, ranging from 15-20 m/s were recorded in Cluj-Napoca, Dej.

\section{DATA AND METHODS}

The identification of the cases of severe convective wind and associated phenomena was made on the basis of the diagnostic data from the Cluj Forecast Service.

The synoptic configurations in which the convective systems were developed were analyzed with data from the ECMWF model (EUMETRAIN source). Factors have been identified that have helped intensify convective systems once formed by accelerating upward currents such as divergence at the top of the troposphere that can be associated with a jet stream, low-level convergence, positive vorticity advection. WV 6.2 water vapor satellite images (EUMETRAIN source) were used to observe both the cloud systems and dry lines, which behave as a line of discontinuity, and if convective cells appear in the area, dry air infiltration contributes to the increase of descending currents as a result of evaporation processes. An important role in the analysis was the conceptual model of the tropospheric jet streak in four quadrants (Adam J. Clark et al, 2009) and the dynamic tropopause (IPV) anomaly (Hoskins et al., 1985). In order to understand the processes and their magnitude in the troposphere, vertical sections were used.

The degree of potential instability and vertical wind shear was evaluated because of their role in organizing the storms. For the assessment of potential instability (using the GFS model), the following indices were used: CAPE (Convective Available Potential Energy), LI, and VTI (Vertical Total Index) was calculated VTI $=\mathrm{Te}(850 \mathrm{mb})-\mathrm{Te}(500 \mathrm{mb})$. The latter indicates the vertical transport of unstable air, when the value of the VTI index is higher than 25, for the northwest of Romania, the strong storms occur with a probability of $62 \%$ (Maier N. 2005).

For the radar analysis of the convective systems, the following products were used: base reflectivity, composite reflectivity, radial velocity from Oradea and Bobohalma radars, and with the aid of VAD (vertical azimuth display), it was analyzed the vertical wind shear. Strong storms develop in strong shear environments that allow the coexistence of ascending and descending currents wich greatly influence the organization and longevity of the storm.

\section{RESULTS AND DISCUSSIONS}

The synoptic configurations in which the convective systems that generated the wind intensifications have some common features the existence of a large trough associated with the Icelandic Low that descends across the west and central Europe and sometimes reaches up to the Mediterranean basin with one or more cut-off lows, and to the east there is a ridge with the axis in the Caspian Sea area or the East Black Sea. This configuration brings the area of interest under the influence of a baroclinic environment 
area with strong horizontal thermal gradients. The air rising at the synoptic scale in the front of the trough means that the northwestern part of Romania is under the influence of a low-pressure system on the ground, favorable to ascending movements and in the lower layers of the troposphere by the presence of a warm air mass.

In these synoptic configurations, latent instability in the atmosphere evaluated for 12 UTC for each day, with the CAPE, LI, VTI parameters (Table 1) is strong. CAPE values indicate the possibility of high instability occurring on 25.07.2017 and 25.05.2012, while values of LI of $-4 \ldots-5$ present in each case, suggest a highly unstable atmosphere. The vertical air transport indicator, VTI, suggests the highly unstable atmosphere with the exception of 25.07.2017 when it is lower.

Table 1. Instability indices for 12 UTC (GFS)

\begin{tabular}{|l|c|c|c|c|c|c|}
\hline & 01.06 .2012 & 05.06 .2012 & 25.05 .2015 & 25.07 .2017 & 03.09 .2017 & 17.09 .2017 \\
\hline CAPE & $>500$ & $>700$ & $>1200$ & $>1100$ & 300 & $50-100$ \\
\hline LI & -4 & -5 & -5 & -5 & -4 & -4 \\
\hline VTI & 28 & 26 & 28 & 24 & 28 & 28 \\
\hline
\end{tabular}

On September 17, 2017, the particularly severe convective wind was generated by a mesoscale convective system, organized as a squall line developing a bow echo, which moved from the central Balkans, crossed the west of Romania from south to north, between $15.00-17.00$ (local time) with an estimated average speed of approx. $90 \mathrm{~km} / \mathrm{h}$. A maximum speed of $41 \mathrm{~m} / \mathrm{s}$ was recorded at Huedin and at Vladeasa 1800 weather stations when crossing the Apuseni Mountains, when the system intensified due to the forced uplift followed by the sudden expansion of the air downstream of the obstacle. In the northwestern part of the country there were values between $25-40 \mathrm{~m} / \mathrm{s}$ at Cluj Napoca, Târgu Lăpuş, Bistriţa, Baia Mare, Zalău, Sighetu Marmaţiei. At that date, the western area of Romania is under the influence of a baroclinic environment, formed by the close contact between a large trough of the Icelandic Low descending up to the Mediterranean Sea, with a cut-off low centered in the Central Germany (552 $\mathrm{gdm}$ ) and a ridge with the axis in the Black Sea region. On the southeastern flank of the altitude trough, there was the formation of a shortwave trough with a very fast northeastern movement, supported by a folding of the dynamic tropopause, where the cold and dry air from the stratosphere penetrates into the troposphere. The presence of a powerful jet stream surrounding the trough, with the left exit area on the west side of Romania, makes in the upper part of the troposphere a strong divergence zone, which can stimulate the development of convective systems once formed. In the conditions of an atmosphere with high potential for severe instability, in the vertical section in the direction of movement of the system Fig. 2, it can be seen the intensification of the circulation on the whole air column, with the intrusion of a dry and cold air that have led to the emergence of a squall line with a strong downward current that generated a derecho. An important contribution to the severity of the wind intensification can be attributed to the rapid penetration of dry air and its mixture to the downward current, evaporation cooling, increasing the downward current. 


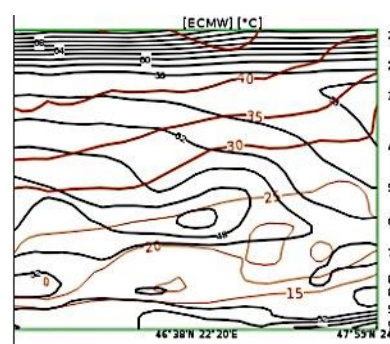

Cross-Section from map Equivalent Potential Temperature and Isotachs

for $45^{\circ} 14^{\prime} \mathrm{N} 20^{\circ} 43^{\prime} \mathrm{E}-47^{\circ} 59^{\prime} \mathrm{N} 24^{\circ} 03^{\prime} \mathrm{E}$, valid $17.09 .201712: 00$
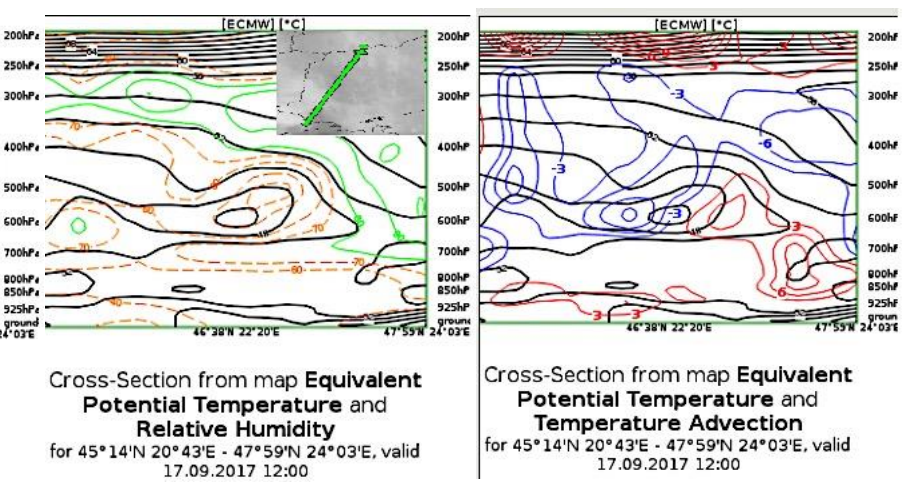

Fig. 2. Vertical section on the storm direction movement at 12 UTC, equivalent potential temperature and izotachs (left), equivalent potential temperature and relative humidity (middle) and equivalent potential temperature and temperature advection (right) ECMWF source.

The pressure tendency distribution at 15 UTC (weather.us) indicates a rapid mass change from 4 to $5 \mathrm{mb}$ drops in front of the squall line, with increases of up to $5 \mathrm{mb}$ behind it. The highest variations in pressure were recorded in areas where the echo intensity was higher. In Fig. 3 in the base reflectivity radar image at 0.5 elevation, it can be seen the arched shape of the echo and its size, the area with intense gradient and in the storm relative velocity image, at all the elevations, one can notice the large area with speeds up to $-33 \mathrm{~m} / \mathrm{s}$ at the enterance of the storm at the 0.5 elevation, the most intense convergence zones being in the maximum echo area with an output speed of $+18.5 \mathrm{~m} / \mathrm{s}$ at the height of $2.0-2.5 \mathrm{~km}$.
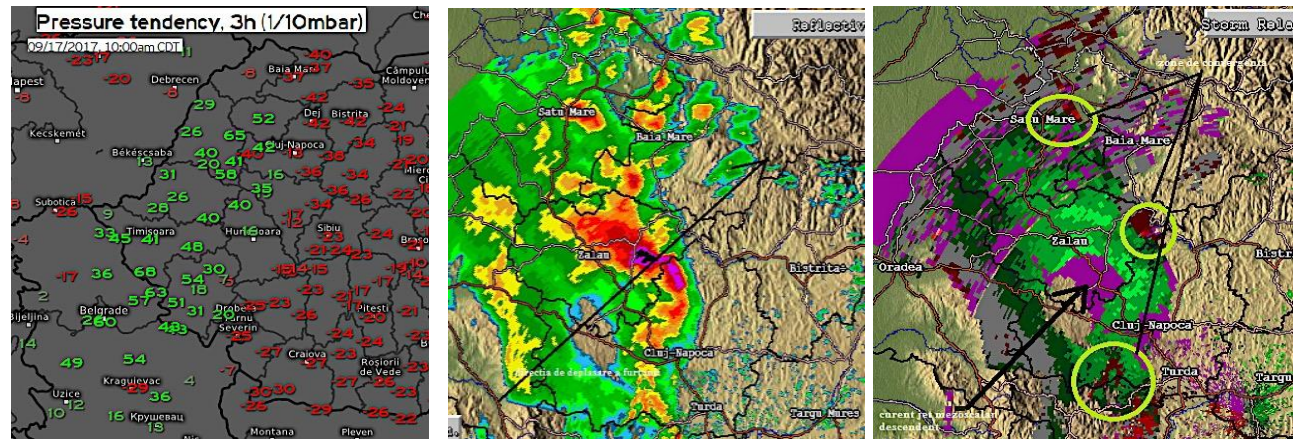

Fig. 3. Pressure tendency at 15 UTC (wearher.us)(left), base reflectivity (middle) and storm relativ velocity (right) at $0.5^{\circ}$ elevation at 14.40 UTC (Bobohalma radar)

The convective wind intensification from Satu Mare and Supuru de Jos on May 25, 2015 , formed in a convergence zone, developed in the western counties of Sălaj and Satu Mare, in the presence of a high instability potential atmosphere, the highest of the cases analyzed. The rising of the air, on the synoptic scale, in this case, is due to the advance to the northeast of the cold cut-off low, centered southwest of the country, belonging to a large trough reaching the central-eastern basin of the Mediterranean Sea, with a large ridge in the east with its axis located in the Caspian Sea. It is noteworthy that the cut-off 
low is also associated with positive anomaly of the PV (Fig. 4) that add a positive vorticity to the tropospheric air column, strong divergence in the upper troposphere and a cold and dry stratospheric air intrusion. All this contributes to rising air.

In the water vapor satellite image, it is noticed that the system is formed in the vicinity of a dry line, the intrusion of dry air into a convective system contributes to the intensification of the descending current, leading to the intensification of the wind at ground surface. In the area in front of the depression, at 12 UTC, visible in water vapor satellite image (Fig. 4), the cold front in the central southern part of Romania was observed, and the warm, slightly outlined front was to the west. The vertical thermal gradient was high $\left(6.5-7.0^{\circ} \mathrm{C} / \mathrm{km}\right)$.

Two of the cells that evolved in the convergence zone developed a supercellular structure, and the radar algorithm identified MEZO and TVS (tornadic vortex signature) structures, indicating a particularly high potential for severe weather. An essential role in the formation of supercellular structures was the vertical wind shear which has strong values at low levels, this is surprised in the vertical movement of air offered by the VAD (vertical azimuth display) product from Oradea radar (Fig. 4). The systems evolved rapidly, being supported on the entire tropospheric air column, had a long-life span, benefiting from the convergence line. The emergence of rotation structures was highlighted by the radar in SRV (storm relative velocity) product. In base reflectivity radar image, at the $0.5^{\circ}$ elevation in Fig. 4 we can detect the V-shape of the structure.
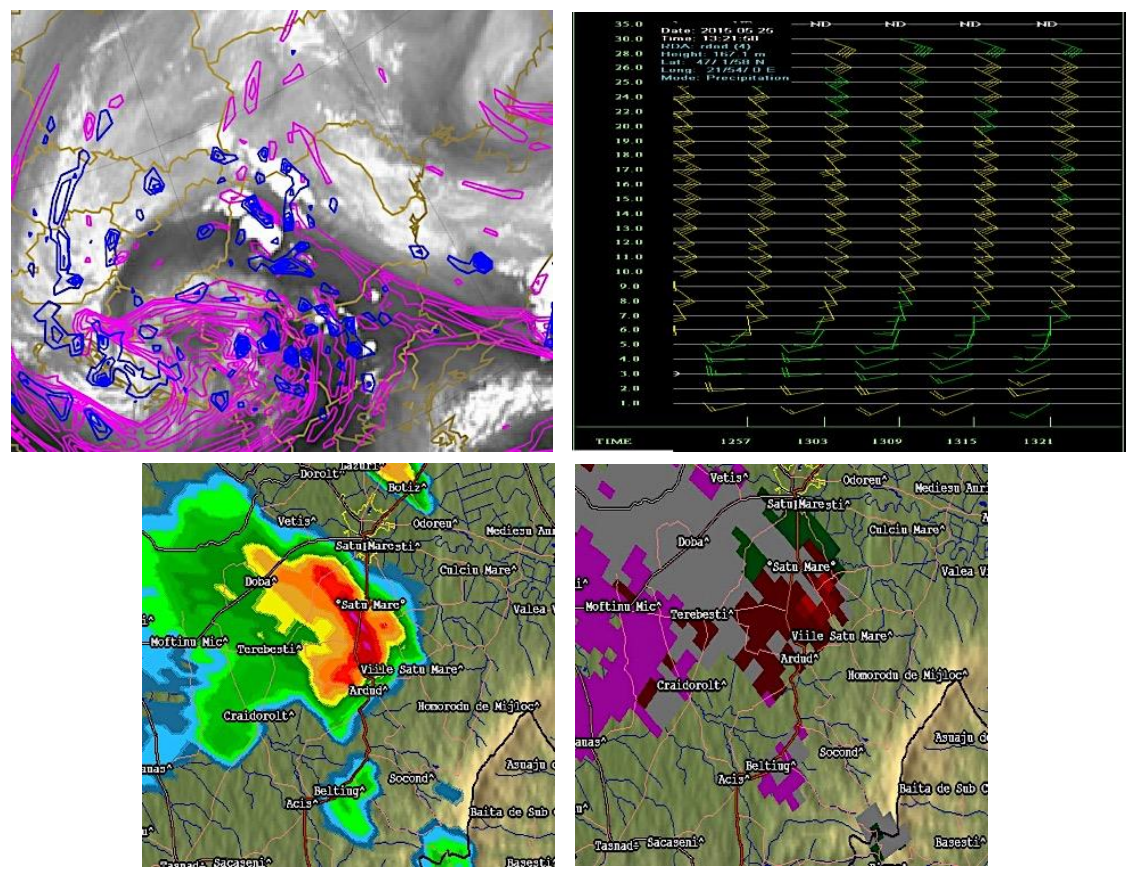

Fig. 4. Water Vapor satellite image WV $6.2 \mathrm{~h} 12$ with relative vorticity, divergence at $300 \mathrm{mb}$ (ECMWF eumetrain upper left); Vertical Azimuth Display la h. 13.20 UTC (upper right), base reflectivity (lower left) and base velocity (lower right) at $0.5^{\circ}$ elevation at 13.03 UTC (Oradea radar)

On July 25, 2017, our country was situated in the contact area between a vast trough, which stretched over most of Europe to the Mediterranean Sea, with a cut-off low above 
Germany (550 gdm), and a ridge with the north-south oriented axis, in the Black Sea area. A shortwave trough associated with the cut-off low centered over central Europe, was moving from south to north over the west of Romania. At the ground surface the air pressure was low $(1000 \mathrm{mb})$. In the lower levels of the troposphere is a confluence zone, with a north-south orientation, also surprised in the streamlines at the level of $850 \mathrm{mb}$ (fig. 5). In this case, the shortwave trough is accompanied in the upper part of the troposphere, by a folding of the dynamic tropopause (Fig. 5), a vorticity advection and divergence in the upper layers of the troposphere which are factors that stimulate the vertical movements. The VAD product from the Oradea radar shows a rotation of the wind from the west, closer to the ground, to the south-east in the upper levels of the troposphere, favorable to the supercellular developments.
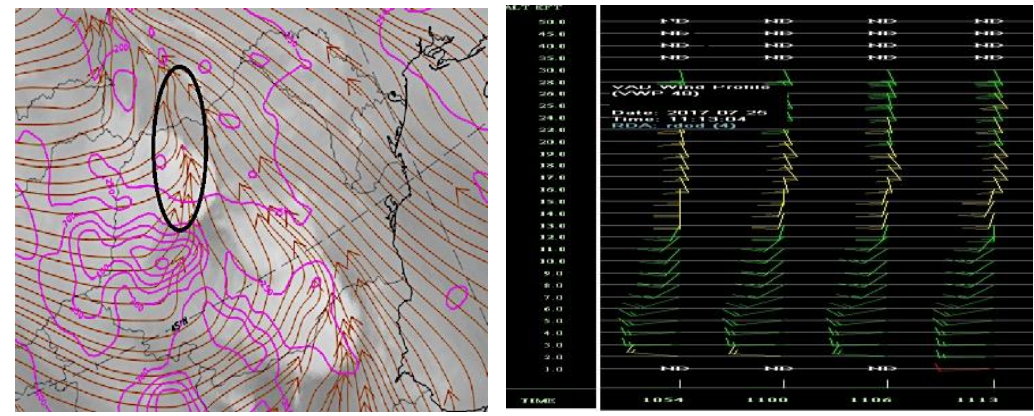

Fig. 5. IPV 1.5 and streamlines at $850 \mathrm{mb}$ overlay WV 6.2 satellite image (ECMWF eumetrain) at 12 UTC (left) and Vertical Azimuth Display at 11.13 UTC radar Oradea (right).

The potential for instability is high, because of the contact between the cold air mass with the high humidity associated with the trough, and the warm and humid air mass from the southeast from the Black Sea. According to the Belgrade sounding, the vertical gradient of temperature is over $8 \% \mathrm{~km}$, significant values of precipitable water content over $40 \mathrm{~mm}$ and high shear in the 0-6 km layer creates a favorable environment for the development of a squall line. In the base reflectivity image at the $1.5^{\circ}$ elevation from the Oradea radar, at 11.13 UTC, one can observe the squall line and the shape of the echoes (Fig. 6), which traversed the northwestern part of Romania from south to north along the confluence area developing a supercellular structure.
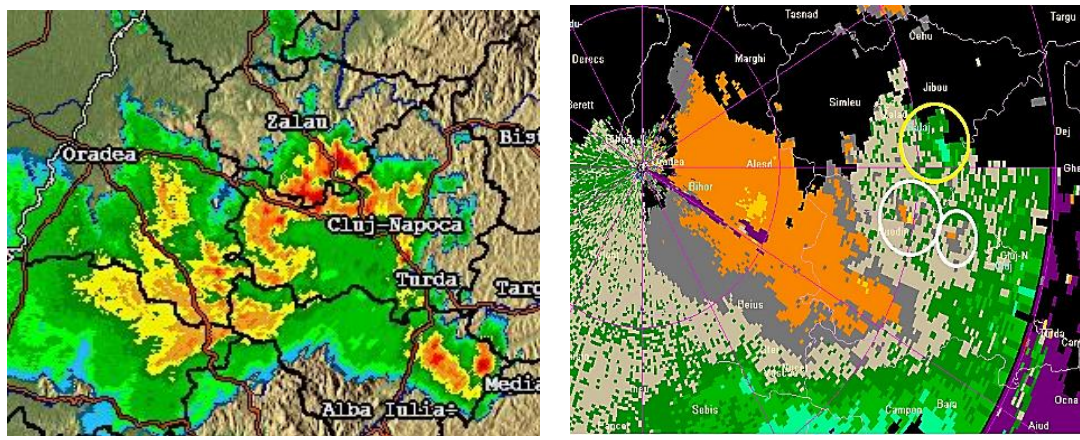

Fig. 6. Base reflectivity, Velocity at $1.5^{\circ}$ elevation at 11.13 UTC radar Oradea. 
The confluence area is also highlighted in the base velocity radar image at the $1.5^{\circ}$ elevation, along with rotational currents, and in front there are visible wind intensification up to $16 \mathrm{~m} / \mathrm{s}$, with yellow in Fig. 6, at the height of $3.4 \mathrm{~km}$.

On June 1 and 5, 2012, there is a configuration similar to the Omega block, with wide trough covering north-western Europe up to the eastern basin of the Mediterranean Sea, comprised by two ridges, one over the Iberian Peninsula and one west of the Caspian Sea. The north-western area of Romania is under the influence of the trough with a cut-off low over the Scandinavian Peninsula.

The wind intensification on 1 June 2012, which at 12.35 UTC reached $25 \mathrm{~m} / \mathrm{s}$ in Bistrita, are due to a supercell developing a bow echo, belonging to a squall line appearing in front of a cold front passage. Base velocity at $0.5^{\circ}$ elevation, at 10 UTC radar Oradea (Fig. 7), highlights the presence of the cold front passage to the east, in the context of a moderate movement from the southwest sector. This moderate circulation on the whole column of air and a more intense current in the immediate vicinity of the soil up to $18 \mathrm{~m} / \mathrm{s}$, are essential to initiate convection and are captured by VAD (vertical azimuth display) product from Bobohalma radar at 12.21 UTC (Fig. 7).
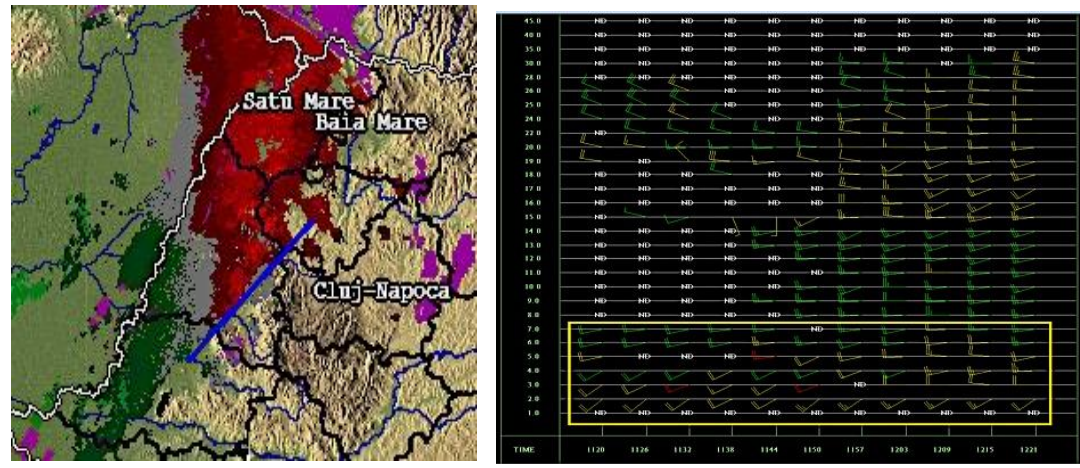

Fig. 7. Base Velocity, elevation 0.5, h 10.00 UTC left (radar Oradea), VAD 12.21 UTC June 01 2012 (right radar Bobohalma)

In Fig. 8 , in base reflectivity image, at $0.5^{\circ}$ elevation, the $\mathrm{Y}$ shape of the radar echo is observed and at the same elevation, in the storm relative velocity image, it can be seen the wind intensifications in front of the system, which at the exit from the storm reached at $16 \ldots 22 \mathrm{~m} / \mathrm{s}$, to the south of Bistrița, at a height of about $1800 \mathrm{~m}$.

In the context of an atmosphere with a potentially severe instability, starting at lunchtime, the area was crossed from west to east by a cold front (white band in Fig. 8), in front of which developed bow echoes and supercells. An important role, in this case, is the presence of a jet streak on the southwest flank of the trough of the Icelandic Low, associated with a dynamic tropopause folding, over Central Europe, accompanied by a shortwave trough. It is observed in the upper part of the troposphere, in the northwest of Romania, starting from 06 UTC the existence of a strong zone of divergence, associated with the left exit from the jet streak, the advection of strong positive vorticity, leading to the acceleration of the upward vertical currents of the 
convective systems once formed. South-west circulation brings warm and wet air masses into the low troposphere, contributing to increased static instability.
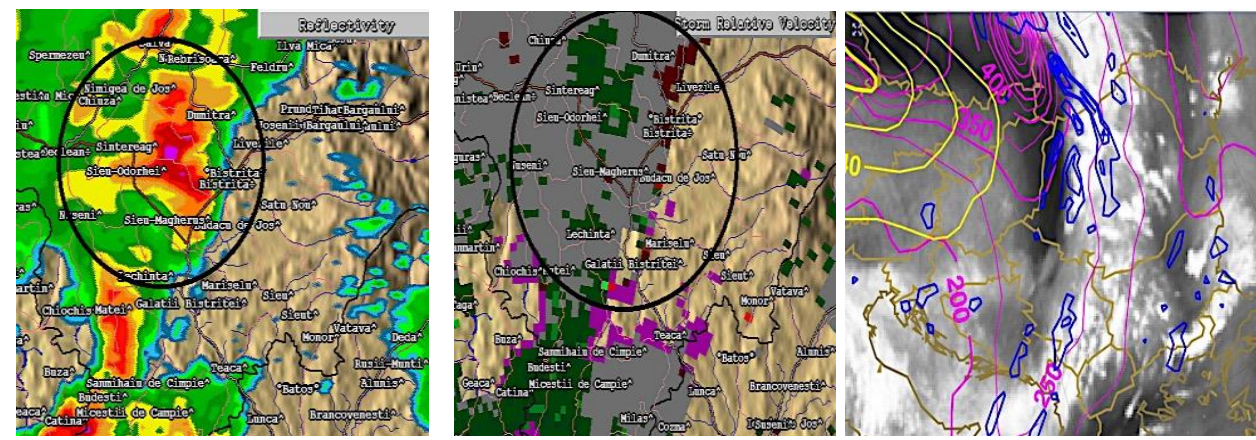

Fig. 8. Base reflectivity (left) Storm relativ velocity (middle), elevation 0.5 h. 12.21 UTC June 01 2012 (radar Bobohalma) June 01201212 UTC. WV.6.2 Satellite image (eumetrain), izotach, divergence at $300 \mathrm{hPa}$ and IPV 1.5 (ECMWF)(right)

On June 5, 2012, the appearance of an altitude disruption on the south-eastern flank of the Icelandic Low, but located somewhat more westward than June 1, with a jet streak to the west and another to the east with the right entrance zone over the north-west of Romania (Fig. 9). This leads to the emergence of a shortwave trough in the western part of Romania, the decrease of the ground pressure and the increase of the western circulation. There is a decrease in ground pressure and a significant pressure gradient from west to est. In the vertical section, one can observe the magnitude of the altitude disruption, in the area of Hungary the dynamic tropopause descends to almost $600 \mathrm{mb}$, it is accompanied by an intrusion of cold and dry air.
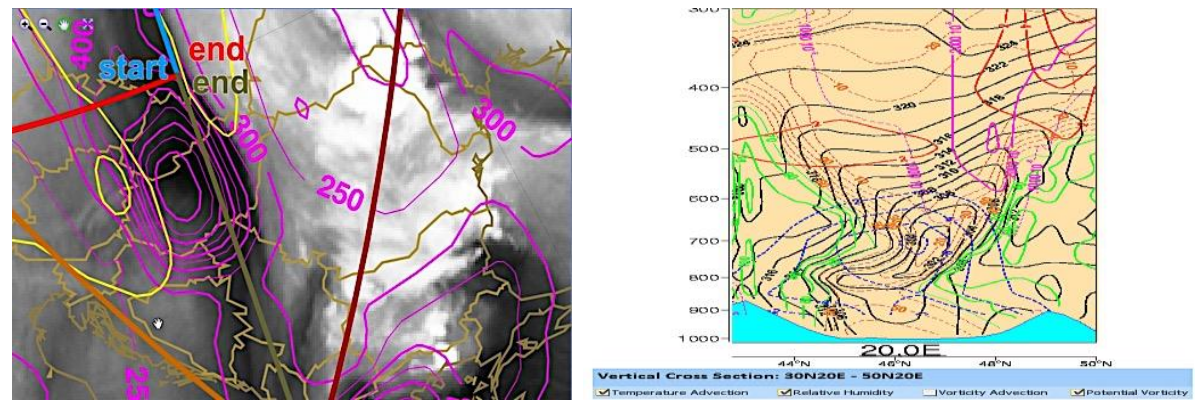

Fig. 9. WV.6.2 Satellite image (eumetrain), izotach at $300 \mathrm{hPa}$ and IPV 1.5 (ECMW)(left), vertical section (khaki) with temperature advection (red, blue, humidity (green, brown), height IPV(magenta) (ECMWF), June 05 2017, 18 UTC

In the conditions of a humid air mass with high potential for severe weather and a gradual cooling in the north-west, the instability is general and is manifested by the emergence of convective systems organized in a squall line with a west-east movement. In this case, a more intense circulating in the lower layers (Fig. 10) is observed. A low-level jet appeared in the base velocity radar image at 15.10 UTC at 
the elevation of 0.5 with a speed up to $18.5 \mathrm{~m} / \mathrm{s}$ and leads to the rapid development of a supercell south of Satu Mare.
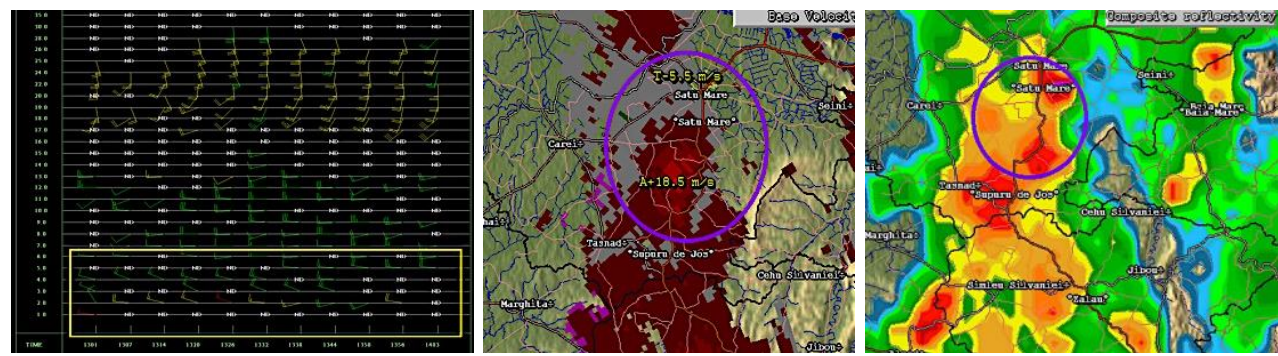

Fig. 10. Vertical Azimuth Display h. 14.03 UTC, Base Velocity h 15.10 elevation 0.5, Base Reflectivity h 15.16 UTC, June 52012 radar Oradea

In a highly unstable atmosphere, on September 3, 2017 (Dej $26 \mathrm{~m} / \mathrm{s}$ ) the area is crossed, from south to north, by a squall line with a supercell structure. In the storm, relative velocity radar image at the elevation of 0.5 , it can be seen an intense convergence area (Fig. 11). When the squall line arrives south-west of Dej, develops a supercellular structure and amplifies when crossing the city. The convergence zone strengthens as altitude increases. An image provided by the VAD product in the Bobohalma radar area indicates an intense southerly air circulation with a maximum of $25.7 \mathrm{~m} / \mathrm{s}$ at $3.4 \mathrm{~km}$, favoring ascending rotation currents. The intense circulation on the entire tropospheric air column is based on a strong east-west pressure gradient at $500 \mathrm{hPa}$, between a ridge to the east, in the central Black Sea basin, with the north-south axis and a trough with a north-south axis, with a cut-off low (560 gdm) above the Ionic Sea. Ascending air on a synoptic scale in front of the trough leads to low ground pressure in the north-west of Romania (1005 mb), which favors upward movements. The slow advance of the trough during the day, leads to gradient growth and increased circulation, as well as the intrusion of cold and dry air into the upper layers, while in the lower ones a warm and humid air is maintained, thus increasing the degree of static instability. The jet streak that surrounds the tip of the trough at 12 UTC has the left exit zone over the northwest of Romania causing divergence, which can contribute to the intensification of the vertical movements of the convective systems once formed.
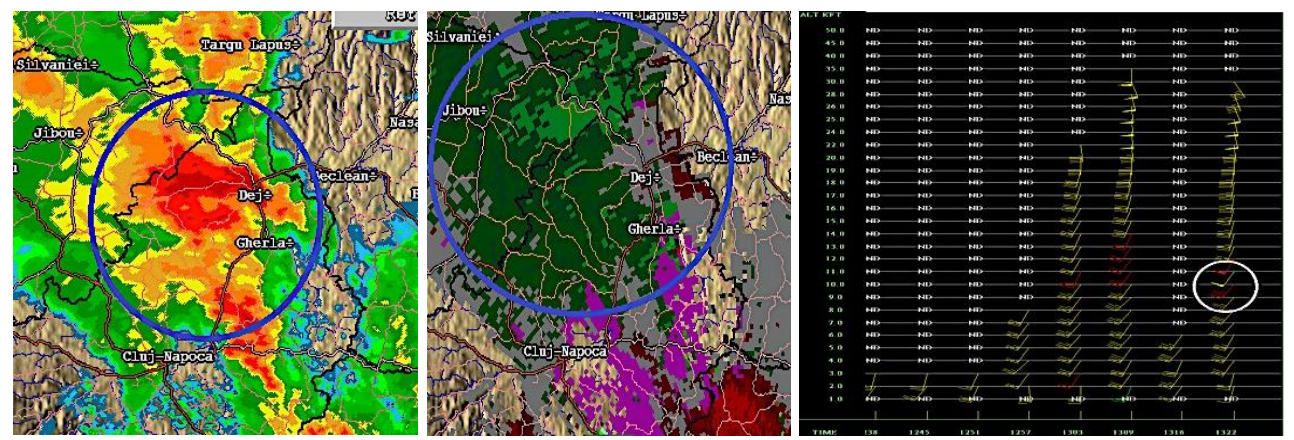

Fig. 11. Base reflectivity (left), SRV(middle) at $0.5^{\circ}$ elevation and Vertical Azimuth Display (right) at h. 13.22 UTC September 3, 2017 radar Bobohalma. 


\section{CONCLUSION}

In all cases, there is a high degree of potential instability, in a synoptic context favorable to upward movements, in the presence of a baroclinic environment and low pressure on the ground. A significant contribution to rising air is due to high tropospheric perturbations: IPV $=1.5$ advection, divergence zones, jet streams associated with the advance of a trough or shortwave perturbations formed at its periphery. The presence of strong wind shear, up to the middle levels of the storm, helped organize the convection systems. Unidirectional vertical shearings contributed to the formation of mesoscale convective systems on September 17, 2017, and to the formation of bow echoes and supercells on June 1, 2012 and September 3, 2017. Rotating convection currents has favored the emergence of supercells on May 25, 2015, July 25, 2017 and June 5, 2012. In the first two cases, supercell systems have benefited from a convergence line.

\section{REFERENCES}

1. Clark, A.J. Schaffer, Ch.J., Gallus Jr., W.A., Johnson-O’Mara, K. (2009) Climatology of Storm Reports Relative to Upper-Level Jet Streaks. Weather and Forecasting, Volume 24, No. 4, p. 1032-1051. https://doi.org/10.1175/2009WAF2222216.1

2. Hoskins, B.J., McIntyre, M.E., Robertson, A.W. (1985) On the use and significance of isentropic potential vorticity maps. Quarterly Journal of the Royal Meteorological Society, Volume 111, Issue 470, Pages 877-946, https://doi.org/10.1002/qj.49711147002

3. Maier, N. (2011) Determination of maximum gust in convection storms SACS 17-18 nov. 2011, ANM, Bucureşti

4. http://www.actualmm.ro/o-furtuna-de-intensitate-neobisnuita-a-lovit-comunacoroieni-in-aceasta-dupa-amiaza/

5. http://www.cpc.ncep.noaa.gov/products/precip/CWlink/daily_ao_index/teleconnections.shtml

6. http://www1.wetter3.de/Archiv/

7. https://dej24.ro/prapad-in-dej-dupa-furtuna-acoperisuri-smulse-copaci-doboratifotovideo/

8. https://weather.us/observations/romania/pressure-change/20170917-1500z.html

9. https://www.eumetrain.org

10. https://www.timponline.ro/o-furtuna-puternica-a-rupt-copaci-a-desprins-acoperisulunui-bloc-si-a-distrus-parbrizele-unor-masini/ 
